\title{
Hot Pressing of TiN-Alumina Composites
}

\author{
Anatolijs KUZJUKĒVIČS, Kozo ISHIZAKI, Jānis GRABIS*, Tālis MILLERS* and Yoshihito KONDO** \\ Nagaoka Gijutsu Kagaku Daigaku (Nagaoka University of Technology), Kamitomioka 1603-1, Nagaoka 940-21 \\ *Institute of Inorganic Chemistry, Latvian Academy of Science, Salaspils, Latvia LV-2169 \\ **Kagawa Prefectural Industrial Technology Center, 587-1, Goto-cho, Takamatsu-shi, Kagawa 761
}

\author{
TiN-アルミナコンポジットのホットプレス焼結 \\ Anatolijs Kuzjukëvičs • 石㠃幸三・Jänis Grabis*・Tālis Millers* ・近藤祥人** \\ 長岡技術科学大学機械系材料設計大講座, 940-21 新潟県長岡市上富岡町 1603-1 \\ *Institute of Inorganic Chemistry, Latvian Academy of Science, Salaspils, Latvia LV-2169 \\ **香川県工業技術センター, 761 香川県高松市郷東町 587-1
}

[Received July 28, 1993; Accepted December 16, 1993]

\begin{abstract}
The hot press sintering of ultrafine $\gamma-\mathrm{Al}_{2} \mathrm{O}_{3}=$ TiN and $\theta$ $\mathrm{Al}_{2} \mathrm{O}_{3}=$ TiN composites was studied. Initial materials were prepared by the hydrolysis of ultrafine $A l N=T i N$ composite powder with the followed preheating at $4.50^{\circ} \mathrm{C}$ in vacum and by mixing $\theta-\mathrm{Al}_{2} \mathrm{O}_{3}$ and $\mathrm{TiN}$ powders, all made by the RF plasma chemical synthesis. The hot pressed samples were dense with no observa. ble open porosity. Even when sintered at a temperature as low as $1500^{\circ} \mathrm{C}$, the composites exhibited good strength, hardmess and fracture toughness. The highest bending strength values were $481 \pm 30 \mathrm{MPa}$ for the hydrolyzed and $472 \pm 60 \mathrm{MPa}$ for the mixed composites. Both composites differ by phases content and changes in lattice parameters of $\alpha=\mathrm{Al}_{2} \mathrm{O}_{3}$ and TiN. This is due to the different water content in initial aluminas used, $\gamma=\mathrm{Al}_{2} \mathrm{O}_{3}$ and $\theta-\mathrm{Al}_{2} \mathrm{O}_{3}$, which resulted in different oxidation states of Ti for the mixed and hydrolyzed composites. The enlargement of the $\mathrm{Al}_{2} \mathrm{O}_{3}$ and $\mathrm{TiN}$ unit cells caused by the dissolution of ${ }^{\prime} i_{2} \mathrm{O}_{3}$ and TiO, results in the lattice softening which together with the other characteristics, is an important factor governing the mechanical properties of sintered composites.
\end{abstract}

Key-worols: Ceramic composite, Ultrafine powders, TiN, Alumina, Hot pressing, Mechanical properties

\section{Introduction}

With the current interest in the application of ceramics as engineering materials, the Ti-Al-O-N system has been extensively investigated.1)-15) Reinforced $\mathrm{Al}_{2} \mathrm{O}_{3}$ composites with TiN exhibit a higher hardness, strength and fracture toughness than those of alumina ceramics. ${ }^{9)}$ With the amount of TiN at about $30 \mathrm{wt} \%$, composites show a good electric conductivity which makes them particularly suitable for machining by electric discharge, enabling the elimination of tedious production steps.

Different sintering techniques, such as pressureless sintering, hot pressing and hot isostatic pressing, have been used to fabricate $\mathrm{Al}_{2} \mathrm{O}_{3}-\mathrm{TiN}$ ceramic composites. Among them, the hot pressing more closely approximates theoretical density, ${ }^{2), 8), 9), 11), 15) ~}$ while the pressureless sintered ceramic composites contain a significant amount of porosity ${ }^{2), 8), 11)}$ even with ultrafine starting powders. ${ }^{12)}$ In the present study, the hot pressing of $\mathrm{Al}_{2} \mathrm{O}_{3}$-TiN composites is investigated using $\mathrm{Al}_{2} \mathrm{O}_{3}$ and $\mathrm{TiN}$ nanosize precursors.

\section{Experimental}

Two kinds of precursor materials were used for the hot press experiments. The first was $\gamma-\mathrm{Al}_{2} \mathrm{O}_{3}$ and TiN composite powders obtained by the hydrolysis of AlN-TiN* ultrafine composite powder with the followed preheating for $1 \mathrm{~h}$ at $450^{\circ} \mathrm{C}$ in a vacuum. The detailed experimental procedure is described elsewhere. ${ }^{12)}$ The second precursor was a mixture of ultrafine $\mathrm{Al}_{2} \mathrm{O}_{3}{ }^{*}$ and $\mathrm{TiN}^{*}$ powders. All the powders used were made by the RF plasma chemical synthesis. The ultrafine $\mathrm{Al}_{2} \mathrm{O}_{3}$ powder consisted mainly of $\theta$-form with some amounts of $\delta$-form. The former composites will be designated hereafter as hydrolyzed composites and the latter-mixed. Both precursors were ball-milled for $12 \mathrm{~h}$ in ethanol with alumina balls in a plastic pot. After drying and crushing them, the powders were hot pressed in nitrogen for th at $1500^{\circ} \mathrm{C}$ at a pressure of $40 \mathrm{MPa}$ in a graphite mold and a plunger coated with $\mathrm{BN}$. A heating rate of $1000 \mathrm{~K} / \mathrm{h}$ was used for all experiments. Characteristics of the powders used are listed in Table 1.

Vickers hardness and fracture toughness were determined with an indentor load of $98 \mathrm{~N}$. The fracture toughness was calculated by the equation $K_{\text {IC }}$ $=0.026 \times E^{1 / 2} P^{1 / 2} \times a \times c^{-3 / 2}$, where $E$ is elastic modulus, $P$ is load, $a$ is half of the dioganal length of the indentor trace, and $c$ is half of the crack length. ${ }^{16)}$ Ten indentations were made for every sample.

Elastic modulus (E-modulus) was measured by the resonant frequency method using bars of dimensions $35 \times 4 \times 3.5 \mathrm{~mm}$ which were cut and polished from pressed samples. These bars were used also for the determination of bending strength in three-point bending with a crosshead speed of $0.05 \mathrm{~mm} / \mathrm{min}$.

\footnotetext{
* Fabricated by Institute of Inorganic Chemistry of the Latvian
} Academy of Sciences. 
Table 1. Characteristics of the Powders Used.

$\mathrm{H}$ : Hydrolyzed Composites, M : Mixed Composites. Specific Surface Area is Given for the Starting TiN-AlN Powder of the Hydrolyzed Composites or TiN and $\mathrm{Al}_{2} \mathrm{O}_{3}$ Values of the Mixed Ones

\begin{tabular}{|c|c|c|c|c|}
\hline Sample & $\begin{array}{c}\text { Specific } \\
\text { surface } \\
\text { area, } \\
\mathrm{m}^{2} / \mathrm{g}\end{array}$ & $\begin{array}{c}\text { Ti fraction, } \\
{[\mathrm{Ti}] /} \\
([\mathrm{Al}]+[\mathrm{Ti}])\end{array}$ & $\begin{array}{l}\text { Cono } \\
\text { TiN }\end{array}$ & $\begin{array}{l}\text { tration } \\
\mathrm{Al}_{2} \mathrm{O}_{3} \\
70\end{array}$ \\
\hline $\mathrm{C}-1(\mathrm{H})$ & 29.3 & 0.070 & 8.4 & 91.6 \\
\hline $\mathrm{C}-2(\mathrm{H})$ & 31.3 & 0.110 & 13.0 & 87.0 \\
\hline $\mathrm{C}-3(\mathrm{H})$ & 33.7 & 0.135 & 15.9 & 84.1 \\
\hline $\mathrm{C}-4(\mathrm{H})$ & 39.0 & 0.208 & 24.1 & 75.9 \\
\hline C-5 (H) & 45.1 & 0.327 & 37.1 & 62.9 \\
\hline C-6 (H) & 75.0 & 0.384 & 42.3 & 57.7 \\
\hline C-7 (M) & \multirow{4}{*}{$\begin{array}{c}22.0(\mathrm{TiN}) \\
29.8\left(\mathrm{Al}_{2} \mathrm{O}_{3}\right)\end{array}$} & 0.127 & 15 & 85 \\
\hline $\mathrm{C}-8(\mathrm{M})$ & & 0.215 & 25 & 75 \\
\hline C-9 (M) & & 0.307 & 35 & 65 \\
\hline C-10 (M) & & 0.452 & 50 & 50 \\
\hline
\end{tabular}

The edges were chamfered to avoid surface defects located at the bar edge. The lattice parameters were measured using $\mathrm{Si}$ as an internal standard.

\section{Results and discussion}

\subsection{Relative density}

Figure 1 shows that relative density, the ratio of bulk and theoretical densities, of the mixed composites reaches $99.1 \%$ and remains almost constant in the investigated range of TiN composition ( Ti fraction). The highest relative density of the hydrolyzed composites is $97.7 \%$, decreasing with Ti fraction. According to the X-ray diffraction pattern (Fig. 2), mix-

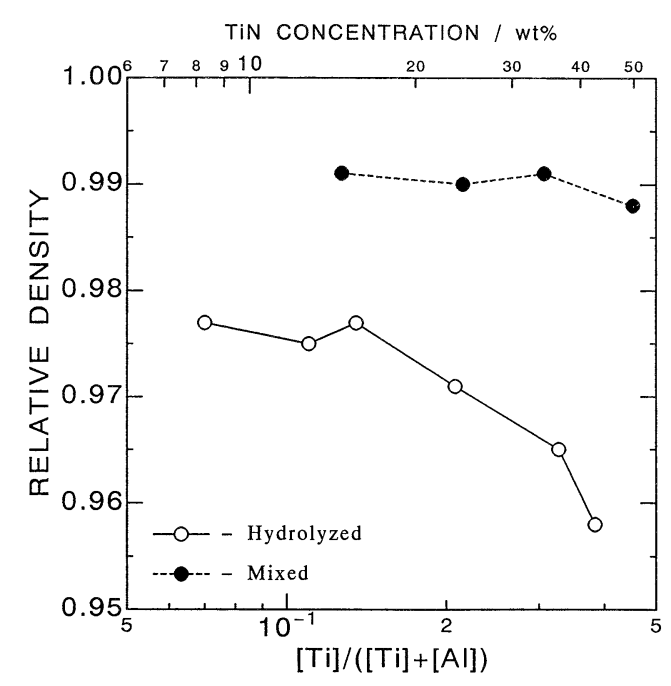

Fig. 1. Relationships between relative density and Ti fraction of the hydrolyzed and mixed composites hot pressed in nitrogen at $1500^{\circ} \mathrm{C}$ for $1 \mathrm{~h}$ with a pressure of $40 \mathrm{MPa}$. ed composites consist of two phases, TiN and $\alpha$ $\mathrm{Al}_{2} \mathrm{O}_{3}$, and only a very small amount of pseudobrookite is detected in composite $\mathrm{C}-10$ with the largest amount of TiN. In contrast, the hydrolyzed composites contain a significant amount of pseudobrookite (Fig. 2). The presence of the third phase is a reason for the lower relative density of the hydrolyzed composites than that of the mixed ones. As seen in Fig. 3, the amount of pseudobrookite increases with Ti fraction. The sharper increase for the composite $\mathrm{C}-6$ might have been caused by the smaller particle size of TiN. The specific surface area of the starting TiN-AlN powder was 2-3 times higher (Table 1) than that of other composites. The larger interface area between the TiN particles and matrix leads to a higher amount of the pseudobrookite when the interaction occurs.

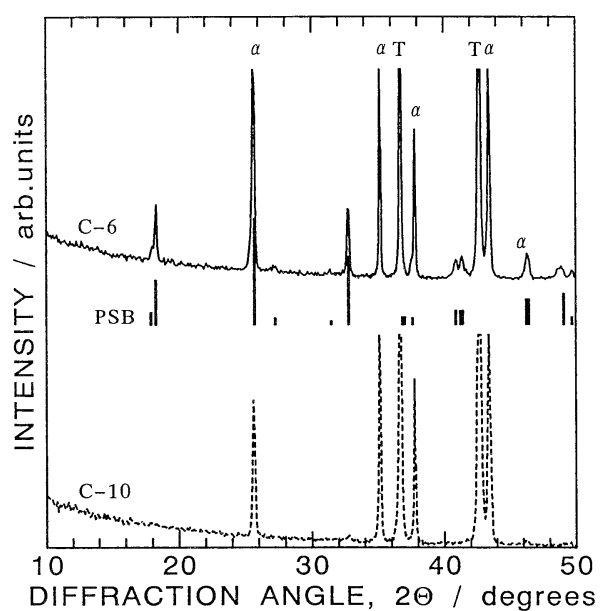

Fig. 2. X-ray diffraction patterns of composites C-6 (hydrolyzed) and $\mathrm{C}-10$ (mixed). The mixed composite consists of TiN (T) and $\mathrm{Al}_{2} \mathrm{O}_{3}(\alpha)$, while the hydrolyzed one contains the third phase, pseudobrookite (PSB).

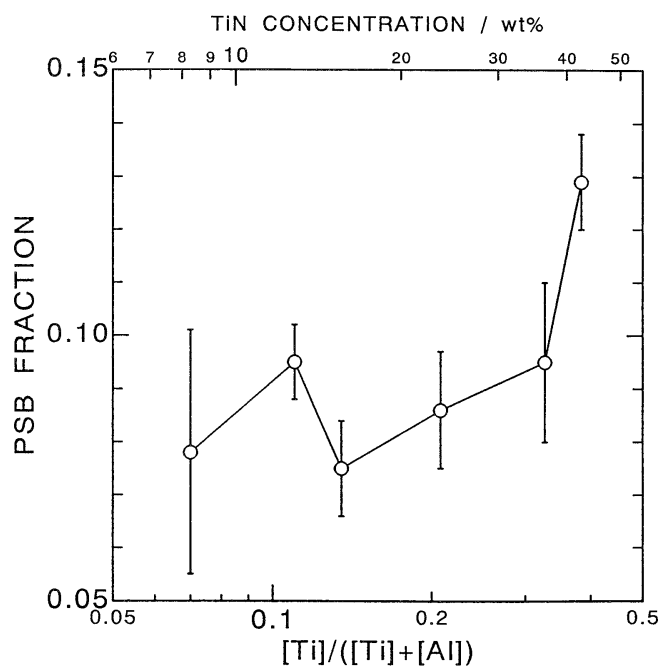

Fig. 3. Relationship between the pseudobrookite and Ti fractions of the hydrolyzed composites. The pseudobrookite fraction was calculated as a ratio of $I_{\mathrm{PSB}, 023} /\left(I_{\mathrm{PSB}, 023}+I_{\mathrm{Alumina}, 104}+I_{\mathrm{TiN}, 111}\right)$ where $I$ is integrated intensity. 


\subsection{Microstructure}

Figure 4 shows the mixed mode of fracture, transand intergranular, for the composites $\mathrm{C}-1$ and $\mathrm{C}-2$. This reveals the formation of mixed composites, intra/intergranular-type. With a larger amount of TiN, the grain size of the matrix decreases sharply and makes it difficult to recognize the type of composite. However, it is believed that the formation of mainly intergranular composites occurs because the grain size of $\mathrm{Al}_{2} \mathrm{O}_{3}$ becomes comparable with that of TiN. The latter assertion is valid also for the mixed composites (Fig. 5).
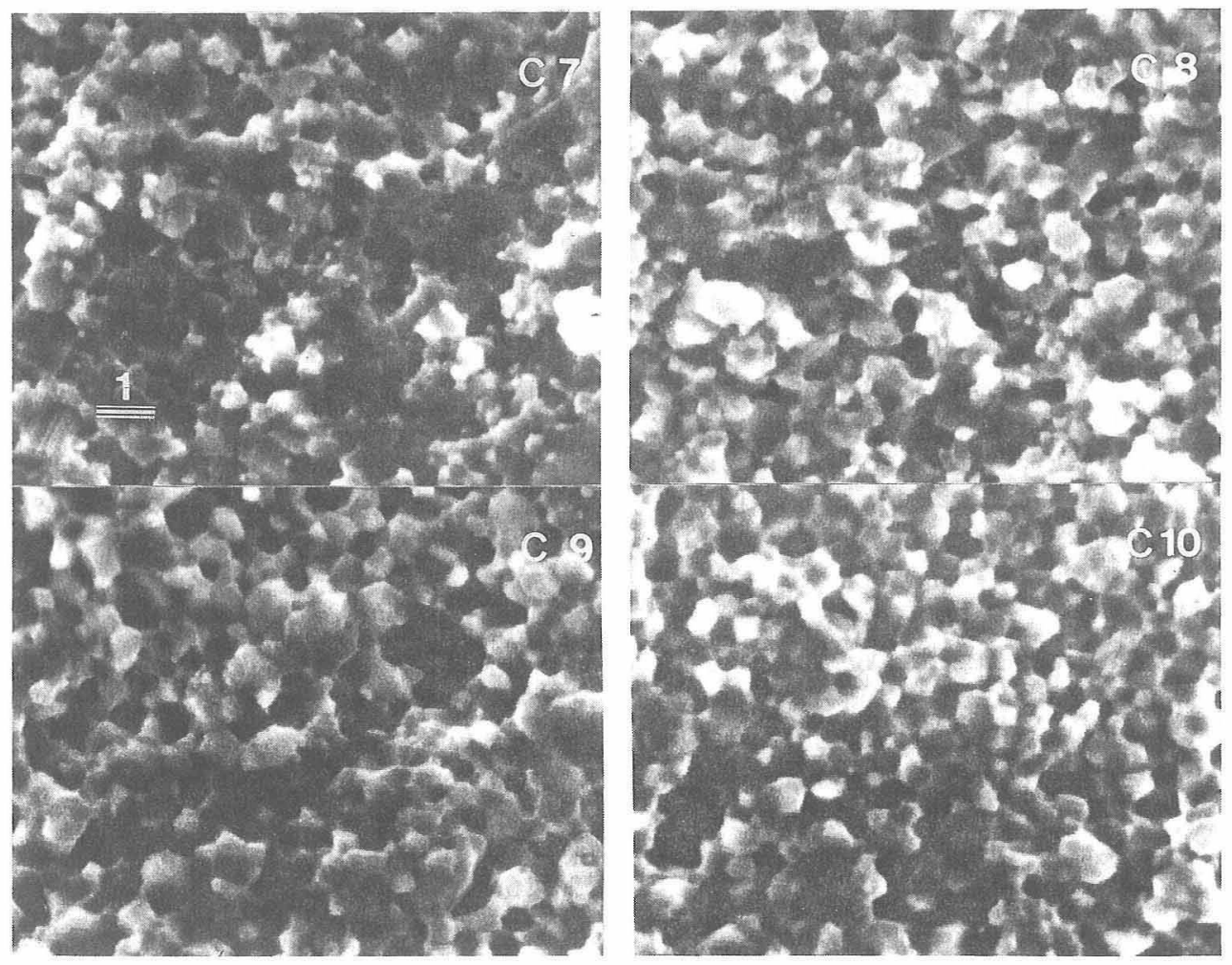

Fig. 4. Fracture surfaces of mixed composites after the hot pressing. Bar $-1 \mu \mathrm{m}$.

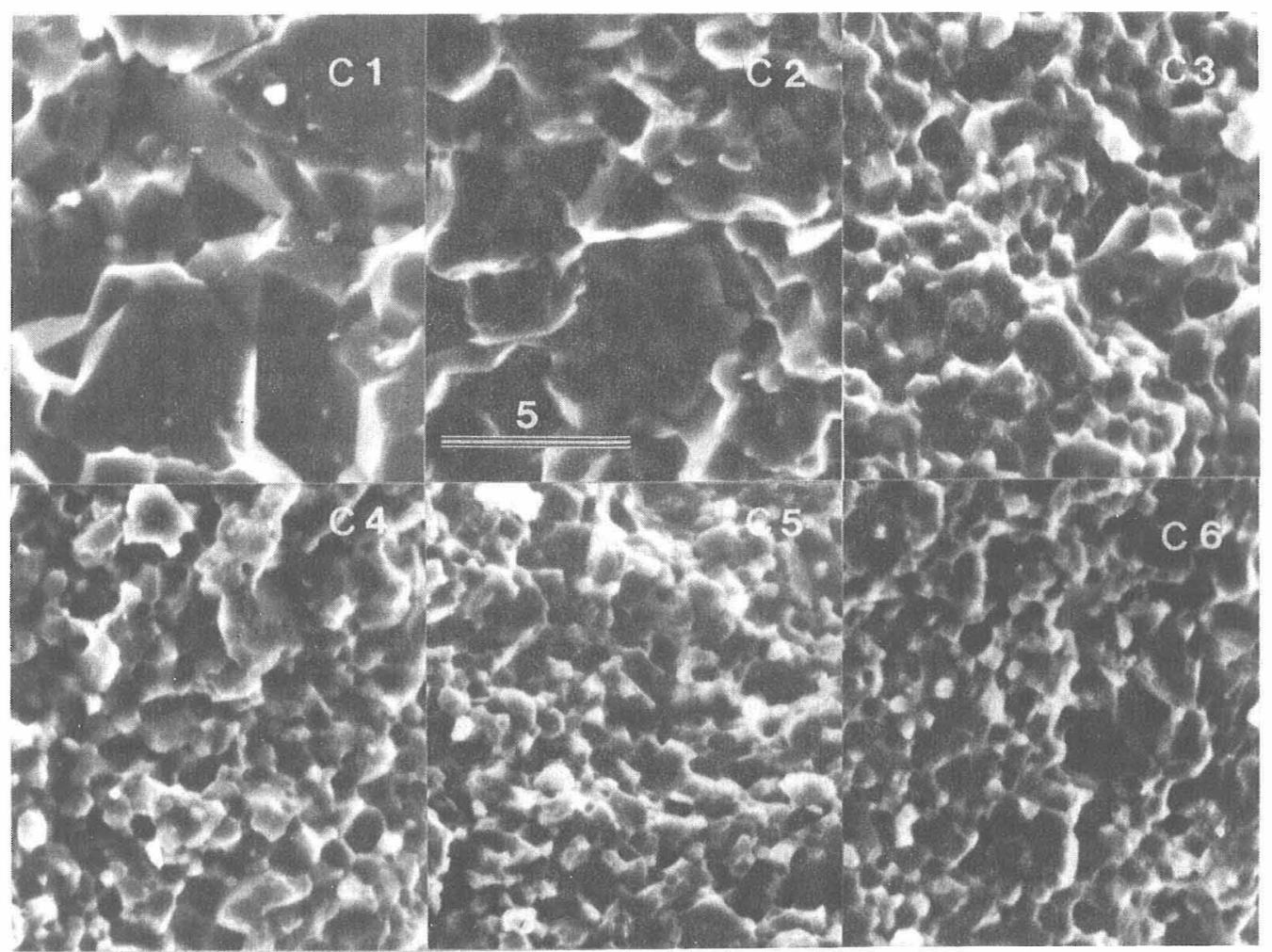

Fig. 5. Fracture surfaces of hydrolyzed composites after the hot pressing. Bar $-5 \mu \mathrm{m}$. 


\subsection{Vickers hardness and fracture toughness}

The relationships between Vickers hardness, fracture toughness and Ti fraction are shown in Fig. 6. For the mixed composites, the value of Vickers hardness is higher with a smaller amount of TiN. A hot pressed composite $\mathrm{C}-7$ with 0.127 of $\mathrm{Ti}$ fraction has the Vickers hardness of $20.7 \pm 0.5 \mathrm{GPa}$. This is higher than the reported value for the $\mathrm{Al}_{2} \mathrm{O}_{3}-\mathrm{TiN}^{3}$ ),9) and AlON-TiN(10),11),13)-15) composites, and pure alumina. ${ }^{17)}$ The hardness decreases with Ti fraction, however, the average grain size remains almost constant in the investigated range of compositions (Fig. 5).

The Vickers hardness of the hydrolyzed composites is smaller compared with that of the mixed ones (Fig. 6). It increases with an increase of Ti fraction from 0.070 to 0.135 . This coincides with the decrease of the grain size as is seen in Fig. 4. Furthermore, the value of the Vickers hardness remains constant, but a decrease is marked for the composite C-6 with the largest amount of pseudobrookite. This implies that the lower value of the Vickers hardness is due to the presence of pseudobrookite in the hydrolyzed composites. A similar trend on the influence of the amount of pseudobrookite has been reported elsewhere in the literature. ${ }^{15)}$

The fracture toughness has almost the same value for both composites, hydrolyzed and mixed, with Ti fraction larger than 0.135 (Fig. 6). Both composites exhibit a small increase of the fracture toughness with the amount of TiN. The higher fracture toughness of the hydrolyzed composites with Ti fraction smaller than 0.135 is believed to be caused by the larger grain size (Fig. 5). The grain size decreases sharply within a narrow interval of Ti fraction from 0.110 to 0.135 . This coincides with the previously reported results on the pressureless sintering of $\mathrm{Al}_{2} \mathrm{O}_{3}-\mathrm{TiN}$ composites. ${ }^{12)}$

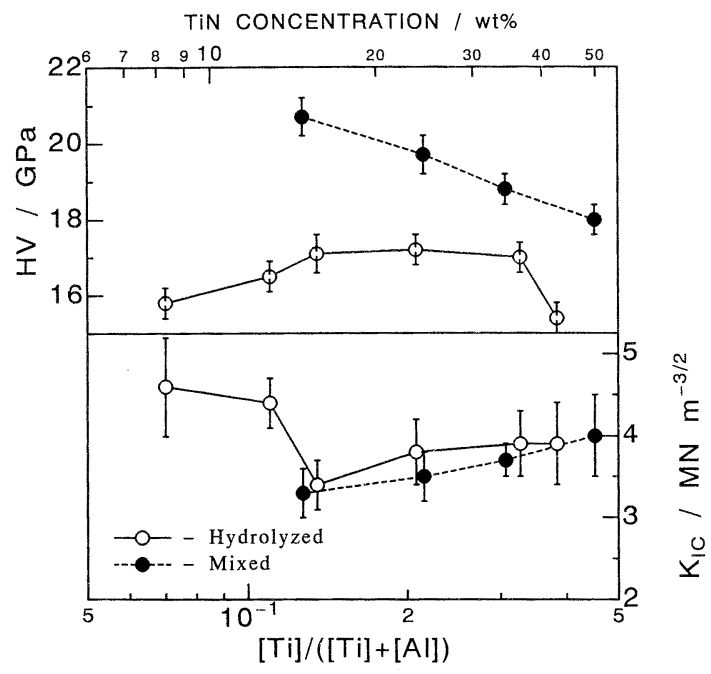

Fig. 6. Vickers hardness $\left(H_{\mathrm{V}}\right)$ and fracture toughness $\left(K_{\mathrm{IC}}\right)$ of the hot pressed composites.

\subsection{E-modulus and bending strength}

The changes of the $E$-modulus with Ti fraction are shown in Fig. 7. As is demonstrated, the $E$-modulus of the mixed composites is higher than that of the hydrolyzed ones. This difference is most likely caused by the presence of the third phase, pseudobrookite, with a lower $E$-modulus than that of $\mathrm{Al}_{2} \mathrm{O}_{3}$ and TiN. It is noteworthy that the $E$-modulus shows a lesser dependence on the amount of TiN. The dependence is smaller than predicted by the calculation model to estimate elastic constants of multiphase materials. ${ }^{18)}$ In contrast, the $E$-modulus of the $\mathrm{Al}_{2} \mathrm{O}_{3}-\mathrm{TiC}$ composites ${ }^{19)}$ was found to correspond well with the calculated $E$-modulus. The bending strength of the hot pressed composites is shown in Fig. 7. The highest strength values were $481 \pm 30 \mathrm{MPa}$ for the hydrolyzed and $472 \pm 60 \mathrm{MPa}$ for the mixed composites. Higher strength values have been reported for the $\mathrm{TiN}-\mathrm{Al}_{2} \mathrm{O}_{3}{ }^{9)}$ and $\mathrm{TiN}$ $\mathrm{AlON}^{10)}$ composites, however, they were hot pressed at much higher temperatures, 1700 and $1900^{\circ} \mathrm{C}$, respectively.

The mixed composites have a slightly lower bending strength than that of the hydrolyzed ones. The bending strength of the latter show a tendency to decrease with $\mathrm{Ti}$ fraction, in contrast to that of the mixed composites. The observed strength behavior for both composites differs from the one expected due to changes in the $E$-modulus, which increases gradually with the amount of TiN (Fig. 7).

A decrease in the strength of the hydrolyzed composites might be caused by the pseudobrookite. However, this contradicts with the reported results of a higher strength value of $\mathrm{Al}_{2} \mathrm{O}_{3}-\mathrm{TiN}$ composites with an increase in the amounts of TiN and pseudobrookite. ${ }^{15)}$ On the other hand, due to a transition from the mixed type composite to mostly a singu-

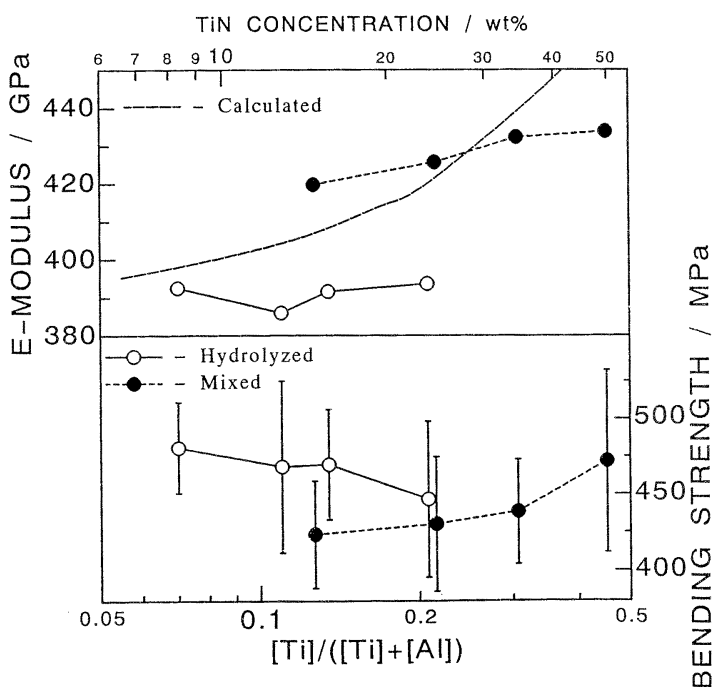

Fig. 7. $E$-modulus and bending strength of the hot pressed composites. For calculation of the $E$-modulus dependence on the TiN amount, $E$-modulus values of $579 \mathrm{GPa}$ for $\mathrm{TiN}^{29)}$ and $386 \mathrm{GPa}$ for $\mathrm{Al}_{2} \mathrm{O}_{3}{ }^{23)}$ were used. 
lar type (Figs. 4 and 5), more grain boundaries of the matrix might have been subjected to a residual compressive stress caused by the difference in the coefficient of thermal expansion of $\mathrm{TiN}$ and $\mathrm{Al}_{2} \mathrm{O}_{3} \cdot{ }^{20), 21)}$ TiN has a higher thermal expansion coefficient $\left(9.0 \times 10^{-6} \mathrm{~K}^{-1}\right.$ within $\left.597-1000^{\circ} \mathrm{C}^{22)}\right)$ than that of $\mathrm{Al}_{2} \mathrm{O}_{3}\left(8.0 \times 10^{-6} \mathrm{~K}^{-1}\right.$ within 25$1000^{\circ} \mathrm{C}^{23)}$ ). This should result in an increase in the bending strength which is seen for the mixed composites, but not for the hydrolyzed ones. This implies that neither the amount of pseudobrookite nor the formation of intertype composites are the only factors which govern mechanical properties of composites.

\subsection{Lattice parameters}

The hot pressing temperature of $1500^{\circ} \mathrm{C}$ used in the present study is high enough to trigger the interaction between components. It becomes particularly significant due to the presence of nanosize TiN particles. The interaction confirmed by the changes of the unit cell volume of $\alpha-\mathrm{Al}_{2} \mathrm{O}_{3}$ (Fig. 8), reveals a different pattern for both composites. For the hydrolyzed composites, the lattice parameters of $\mathrm{Al}_{2} \mathrm{O}_{3}$ are larger compared to the tabular values of corundum. ${ }^{24)} \mathrm{Be}$ sides, the unit cell volume demonstrates a tendency to decrease with Ti fraction, which is completely opposite to that of the mixed composites. For the latter, the lattice parameters of $\mathrm{Al}_{2} \mathrm{O}_{3}$ almost coincide with the tabular values at a low TiN amount, but afterwards increase remarkably. Comparable results of the changes of the lattice parameters of $\mathrm{Al}_{2} \mathrm{O}_{3}$ for the mixed type composites have been reported elsewhere in the literature. ${ }^{2)}$ These are caused by the formation and dissolution of the $\mathrm{Ti}_{2} \mathrm{O}_{3}$ in the $\alpha-\mathrm{Al}_{2} \mathrm{O}_{3}$ lattice. ${ }^{2), 25), 26)}$

A noted difference in the changes of $\mathrm{Al}_{2} \mathrm{O}_{3}$ lattice parameters originates in dissimilar starting powders. They were $\gamma-\mathrm{Al}_{2} \mathrm{O}_{3}+\mathrm{TiN}$ for the hydrolyzed composites and $\mathrm{Al}_{2} \mathrm{O}_{3}+\mathrm{TiN}$ for the mixed ones where $\mathrm{Al}_{2} \mathrm{O}_{3}$ represented mainly $\theta$-form with some amount of $\delta$-form. The water content is $2.0 \mathrm{wt} \%$ for the $\gamma$ -

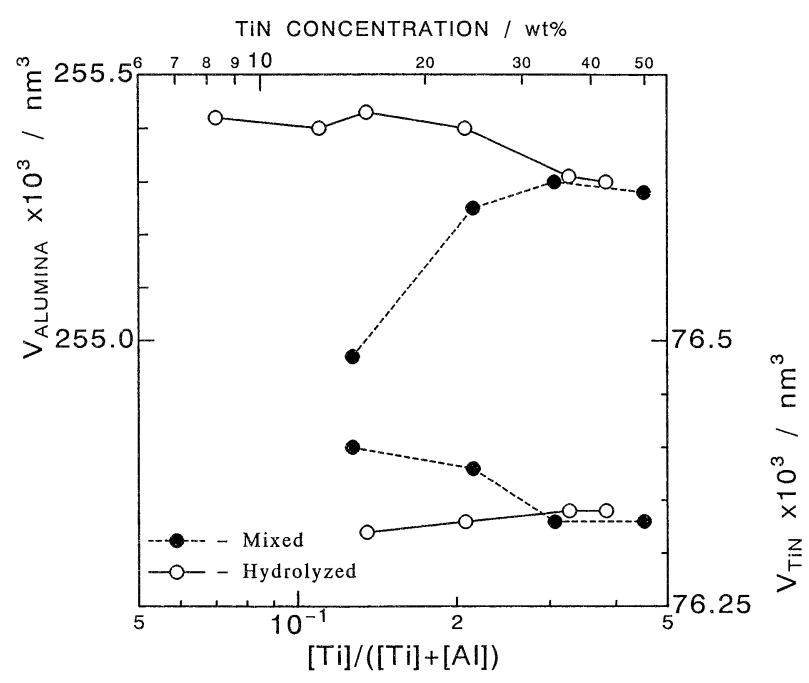

Fig. 8. Volume of $\mathrm{Al}_{2} \mathrm{O}_{3}$ and TiN unit cells.
$\mathrm{Al}_{2} \mathrm{O}_{3}, 1.2 \mathrm{wt} \%$ for the $\delta-\mathrm{Al}_{2} \mathrm{O}_{3}$, and $0.35 \mathrm{wt} \%$ for the $\left.\theta-\mathrm{Al}_{2} \mathrm{O}_{3}{ }^{27}\right)$ The difference is large enough to cause different oxidation states of $\mathrm{Ti}$ when the interaction starts. For the hydrolyzed composites with a larger $\left[\mathrm{H}_{2} \mathrm{O}\right] /[\mathrm{Ti}]$ ratio, the formation of mainly $\mathrm{Ti}_{2} \mathrm{O}_{3}$ and $\mathrm{Ti}_{3} \mathrm{O}_{5}$ might occur. ${ }^{28)}$ The latter forms the pseudobrookite, the former partially dissolves in $\alpha-\mathrm{Al}_{2} \mathrm{O}_{3}$ and pseudobrookite to form $\mathrm{Ti}$ enriched pseudobrookite. A decrease in the lattice parameters of $\mathrm{Al}_{2} \mathrm{O}_{3}$ with Ti fraction might be a result of an increase in the amount of pseudobrookite (Fig. 3) and preferential dissolution of $\mathrm{Ti}_{2} \mathrm{O}_{3}$ in formed pseudobrookite. No formation of the TiO occurs which would dissolve in TiN. Therefore, TiN in the hydrolyzed composites show almost no changes in the lattice parameter (Fig. 8). However, this conclusion requires additional confirmation because the TiN lattice parameter passes a maximum with the replacement of nitrogen by oxygen. ${ }^{4)}$

For the mixed composites with smaller $\left[\mathrm{H}_{2} \mathrm{O}\right] /$ [Ti] ratio, the formation of mainly $\mathrm{TiO}$ and $\mathrm{Ti}_{2} \mathrm{O}_{3}$ should occur. ${ }^{28)}$ The former dissolves in TiN while the latter-in $\alpha-\mathrm{Al}_{2} \mathrm{O}_{3}$. Parameters for both TiN and $\mathrm{Al}_{2} \mathrm{O}_{3}$ increase, but with opposite signs with the amount of TiN (Fig. 8). This seems contradictory upon first inspection.

\subsection{Mechanical characteristics and lattice parameters}

According to Matsushita and Mizuno, ${ }^{30}$ the mechanical properties of the $\mathrm{Al}_{2} \mathrm{O}_{3}-\mathrm{Cr}_{2} \mathrm{O}_{3}$ and $\mathrm{Al}_{2} \mathrm{O}_{3}$ $\mathrm{Ga}_{2} \mathrm{O}_{3}$ solid solutions are strongly affected by the amount of dopant. Since the radius of chromium and gadolinium ions is larger than that of aluminum, the lattice parameters of the solid solutions increase with the amount of dopant. This is accompanied by a decrease of the solid solutions $E$-modulus and is due to changes in the electronic structure of the alumina lattice. This might be the case also for the TiN$\mathrm{Al}_{2} \mathrm{O}_{3}$ composites.

As a result of the incorporation of $\mathrm{Ti}\left(r_{\mathrm{Ti}^{+3}}=0.076\right.$ $\left.\mathrm{nm}^{31)}\right)$ in $\alpha-\mathrm{Al}_{2} \mathrm{O}_{3}\left(r_{\mathrm{Al}^{+3}}=0.051 \mathrm{~nm}^{31)}\right)$ and $\mathrm{O}$ in TiN, both lattices are enlarged and should be softened. Therefore, the lattice changes shown in Fig. 8 must be associated with changes in the $E$-modulus which varies with composition as shown in Fig. 7. For the mixed composites, a transition from $\operatorname{TiN}_{x} \mathrm{O}_{y}$ (large lattice parameter) towards $\mathrm{TiN}$ (small lattice parameter) is accompanied by the dissolution of $\mathrm{Ti}_{2} \mathrm{O}_{3}$ in $\alpha-\mathrm{Al}_{2} \mathrm{O}_{3}$ which lattice parameters increase. It might be the reason for a very slow increase of the $E$-modulus when softening of the alumina lattice overcomes almost the effect of matrix reinforcement by the TiN particles. This results in relatively small changes in the mechanical properties, bending strength and fracture toughness, with the amount of TiN. However, the Vickers hardness seems to be more influenced by the softening of the $\mathrm{Al}_{2} \mathrm{O}_{3}$ lattice.

The presence of pseudobrookite makes it much more complicated to recognize whether the effect of 
$\mathrm{Al}_{2} \mathrm{O}_{3}$ lattice softening influences significantly the mechanical properties of the hydrolyzed composites. The small amount of the pseudobrookite might act as a $\mathrm{Al}_{2} \mathrm{O}_{3}$ and $\mathrm{TiN}$ grains bonding layer which results in an increase of the bending strength for composites with a small TiN amount. However, composites of this region differ by the larger grain size and formation of the mixed type composites which can also affect the mechanical properties. For both composite types, hydrolyzed and mixed, mechanical properties are also influenced by changes in the thermal expansion coefficients of $\alpha-\mathrm{Al}_{2} \mathrm{O}_{3}$ and TiN caused by the dissolution. Therefore these issues, as well as the lattice softening, deserve further investigation.

\section{Conclusions}

The hot press sintering of ultrafine $\gamma-\mathrm{Al}_{2} \mathrm{O}_{3}-\mathrm{TiN}$ and $\theta-\mathrm{Al}_{2} \mathrm{O}_{3}-\mathrm{TiN}$ composites was studied. The initial materials were prepared by either the hydrolysis of ultrafine AlN-TiN composite powder or by mixing ultrafine $\theta-\mathrm{Al}_{2} \mathrm{O}_{3}$ and TiN powders, all made by RF plasma chemical synthesis. The hot pressed samples were dense with no observable open porosity. Even when sintered at temperature as low as $1500^{\circ} \mathrm{C}$, the composites show good strength, hardness and fracture toughness.

The composites fabricated from the mixed powders consist of $\alpha-\mathrm{Al}_{2} \mathrm{O}_{3}$ and TiN, while the third phase, pseudobrookite, is present in the hydrolyzed composites. This is due to the different water content in initial aluminas used, $\gamma-\mathrm{Al}_{2} \mathrm{O}_{3}$ and $\theta$-form, which resulted in different oxidation states of $\mathrm{Ti}$, $\mathrm{TiO}$ and $\mathrm{Ti}_{2} \mathrm{O}_{3}$ for the mixed composites, and $\mathrm{Ti}_{2} \mathrm{O}_{3}$ and $\mathrm{Ti}_{3} \mathrm{O}_{5}$ for the hydrolyzed ones.

The enlargement of the $\mathrm{Al}_{2} \mathrm{O}_{3}$ and TiN unit cells caused by the dissolution of $\mathrm{Ti}_{2} \mathrm{O}_{3}$ and $\mathrm{TiO}$, results in the lattice softening which, together with the other characteristics, is an important factor governing the mechanical properties of sintered composites.

Acknowledgements The authors are thankful to Mr. M. Dehler, a graduate student of Fachhochschule Rheinland-Pfalz, HöhrGrenzhausen, Germany, and to Mr. R. Gnanamoorthy, doctoral student of Nagaoka University of Technology, Japan, for assistance in experimental work. The authors also wish to thank Mr. K. Watanabe of Maruki Tekkosho Co., Ltd., Niigata, Japan, for grinding and polishing of sintered ceramics.

\section{References}

1) A. Mocellin and G. Bayer, J. Mater. Sci., 20, 3697-704 (1985).

2) J. D. Mnatsakanyan, Yu. N. Vil'k, Yu. N. Paputskii, L. V. Kozlovskii and S. S. Ordan'yan, Poroshk. Metall. (Powder Metallurgy, USSR), 11, 32-38 (1985).

3) J. Mukerji and S. K. Biswas, J. Am. Ceram. Soc., 73, 142-45 (1990).
4) D. S. Perera, Br. Ceram. Trans. J., 89, 57-60 (1990).

5) J. L. Hoyer, J. P. Bennett and K. J. Liles, Ceram. Eng. Sci. Proc., 11, 1423-39 (1990).

6) T. Sperisen and A. Mocellin, J. Mater. Sci., 27, 1121-28 (1992).

7) T. Sperisen and A. Mocellin, J. Mater. Sci., 27, 1129-35 (1992).

8) D. S. Perera, S. Moricca and S. Leung, "Hot Isostatic Pressing. Theory and Application”, Ed. by M. Koizumi, Elsevier Applied Science (1992) pp. 439-44.

9) A. Tampieri and A. Bellosi, J. Am. Ceram. Soc., 75, 1688-90 (1992).

10) Y. G. Gogotsi, F. Portz and V. P. Yaroshenko, J. Am. Ceram. Soc., 75, 2251-59 (1992).

11) J. L. Hoyer, J. P. Bennett and J. A. Clark, 95th Annual Meeting of the American Ceramic Society, Cincinnati, OH, April $18-22,1993$

12) A. Kuzjukēvičs, M. Dehler, K. Ishizaki, J. Grabis and J. Kriegesmann, Mater. Manufac. Processes (1994) (in press).

13) D. S. Perera, "Ceramics, Adding the Value", Ed. by M. J. Banister, CSIRO, Australia (1992) pp. 545-50.

14) D. S. Perera, D. J. Cassidy and M. Ripley, Key Eng. Mater. 48-50, 338-43 (1990).

15) M. Tuey, E. Savrun and C. F. Chen, Mater. Sci. Monogr., 68, 593-98 (1991).

16) Testing Methods for Fracture Toughness of High Performance Ceramics, JIS R 1607, Japanese Standards Association, Tokyo, 1990.

17) R. Matsuki, H. Ueda, T. Takenouchi, A. Nakahira and K. Niihara, J. Jpn. Sci. Powder Powder Metall., 38, 365-68 (1991).

18) B. Paul, Trans. Metall. Soc. AIME, 218, 36-41 (1960).

19) R. P. Wahi and B. Ilschner, J. Mater. Sci., 15, 875-85 (1980).

20) K. Nihara, A. Nakahira, T. Uchiyama and T. Hirai, "Fracture Mechanics of Ceramics", Vol. 7, Ed. by R. C. Bradt, A. G. Evans, D. P. H. Hasselman and F. F. Lange, Plenum, N. Y. (1986) pp. 103-16.

21) R. W. Davidge, "High Tech Ceramics", Ed. by P. Vincenzini, Elsevier Sci. Publ., Amsterdam (1987) pp. 763-77.

22) "Engineering Property Data on Selected Ceramics, Vol. I, Nitrides", Metals and Ceramics Information Center, Battelle Columbus Laboratories, Columbus, OH, 1976.

23) "Handbook of Materials and Processes for Electronics", Ed. by C. A. Harper (1970) p. 6.18 .

24) Powder Diffraction File, Card No. 10-173, Joint Committee on Powder Diffraction Standards, Philadelphia, Pennsylvania (1967).

25) S. K. Roy and R. L. Coble, J. Am. Ceram. Soc., 51, 1-6 (1968).

26) D. S. Perera and M. E. Bowden, J. Mater. Sci., 26, 1585-87 (1991).

27) Kirk-Othmer, "Encyclopedia of Chemical Technology", Third ed., Vol. 2, John Willey \& Sons, N. Y. (1978) p. 228.

28) "Phase Diagrams for Ceramists, 1969 Supplement", Ed. by E. M. Levin, C. R. Robin and H. F. McMurdie, The American Ceramic Society, Columbus, OH (1969) Fig. 2081.

29) J. Wernisch, W. Wruss, Ch. Nissel and B. Lux, Sprechsaal, 118, 921-27 (1985).

30) K. Matsushita and K. Mizuno, Proc. 1993 Fall Meeting of the Japan Inst. of Metals, Nagoya, October 16-18 (1993) p. 115.

31) D. Goldberg, Rev. Int. Hautes Temper. et Réfract., 5, 181-94 (1968). 